\title{
ANALISIS MAQASHID SYARIAH DALAM PENGEMBANGAN HUKUM INDUSTRI HALAL DI INDONESIA
}

\author{
Siska Lis Sulistiani \\ Prodi Hukum Keluarga Islam Fakultas Syariah \\ Universitas Islam Bandung \\ Email: siscaassidq@yahoo.co.id
}

\begin{abstract}
Abstrak
Islam merupakan agama yang rahmatan lil'alamin bukan hanya mengatur urusan ibadah saja, tetapi hingga seluruh aspek kehidupan manusia. Manusia merupakan subjek hukum sekaligus sebagai pelaku ekonomi yang unik dan prospektif, dengan berkembangnya segala kebutuhan dari segala sektor industri sebagai muslim dituntut berada dalam kerangka aturan syariah yaitu halal dan kerangka etika yaitu thayib. Maka perkembangan industri halal khususnya di Indonesia menjadi sangat menarik dan bersifat progresif, sehingga perlunya terus diawasi dalam kerangka maqashid syariah. Oleh karena itu, nilai manfaat dan perkembangannya menghasilkan nilai ekonomi yang tinggi untuk pembangunan negara juga berkah karena berdasarkan syariah. Penelitian ini berdasarkan pendekatan yuridis normatif melalui sumber data sekunder yang terdiri dari sumber hukum primer, sekunder dan tersier, serta dikumpulkan melalui metode dokumneter atau library research dan dianalisis melalui metode deskriptif kualitatif sehingga mealui metode tersebut dapat diketahui analisis yuridis dari maqashid syariah dalam pengembangan industri halal di Indonesia.
\end{abstract}

Kata Kunci: maqashid Syariah, Industri, Halal, Obat.

\section{Pendahuluan}

\section{Latar Belakang}

Indonesia negara yang kaya dari sisi sumber daya manusia maupun sumber daya alam sebagai anugerah dari Allah SWT. Potensi yang besar tersebut sangat berpengaruh terhadap perkembangan industri di Indonesia baik industri pariwisata, sandang, papan, pangan, dan obatobatan. Dengan jumlah penduduk mayoritas muslim di Indonesia menjadikan standar dalam peminatan sektor industri halal dari berbagai macam aspek menjadi meningkat. Peningkatan minat terhadap sektor industri halal di Indonesia tersebut merupakan bagian dari komitmen keislaman yang harus senantiasa ada dalam kehidupan sehari-hari seorang muslim.

Dalam Islam untuk memenuhi kebutuhannya, seorang muslim harus senantiasa sejalan dengan Alquran dan Sunah. Dari segi kualitas, setiap muslim bukan hanya harus memperhatikan halal tidaknya sebuah produk, namun juga tentang nilai 
ke-thoyib-an (baik) untuk kesehatan selain aspek 'rasa' yang sering menjadi pilihan. Sebagaimana firman Allah SWT:
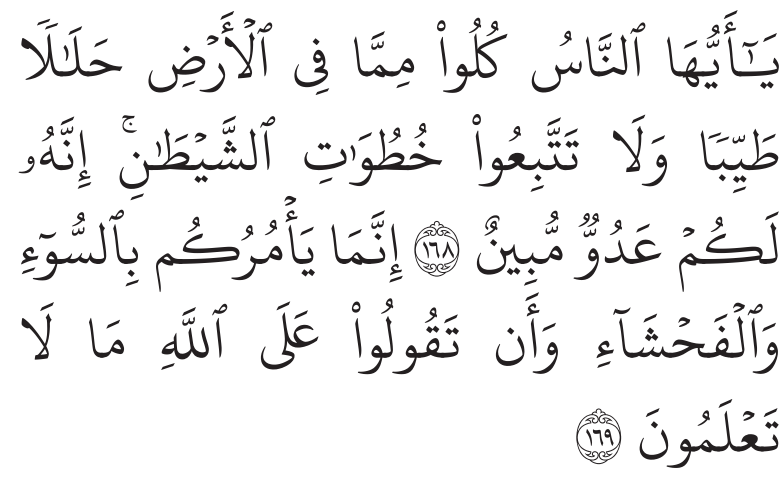

"Hai sekalian manusia, makanlah yang halal lagi baik dari apa yang terdapat di bumi, dan janganlah kamu mengikuti langkah-langkah syaitan; karena sesungguhnya syaitan itu adalah musuh yang nyata bagimu. Sesungguhnya syaitan itu hanya menyuruh kamu berbuat jahat dan keji, dan mengatakan terhadap Allah apa yang tidak kamu ketahui. "(Qs. Al-Baqarah: 168-169)

Pemahaman yang baik tentang agama semakin membuat umat Islam menjadi semakin selektif dalam pemilihan produk yang dikonsumsi. Khusus di Indonesia, umat Islam dilindungi oleh lembaga yang secara khusus bertugas untuk mengaudit produk-produk yang dikonsumsi oleh Umat Islam di Indonesia. Lembaga ini adalah Lembaga Pengawasan dan Peredaran Obat dan Makanan Majelis Ulama Indonesia (LPPOM MUI). Lembaga ini mengawasi produk yang beredar di masyarakat dengan cara memberikan sertifikathalal sehingga produk yang telah memiliki sertifikat halal tersebut dapat memberi label halal pada produknya (MUI, 2016). Kemudian di tahun 2017, diresmikan Badan Penyelenggara Jaminan Produk Halal (BPJPH) melalui ketentuan UndangUndang Nomor 33 Tahun 2014 tentang Jaminan Produk Halal. Setelah beroperasinya BPJPH, peran dan kewenangan MUI tetap penting dan strategis yaitu memberikan fatwa penetapan kehalal an suatu produk yang kemudian disampaikan kepada BPJPH sebagai dasar untuk penerbitan sertifikat halal. Sertifikat halal yang dikeluarkan oleh MUI selama ini tetap berlaku sampai jangka waktunya habis. Sinergi dan kerja sama BPJPH dengan MUI antara lain dalam hal Sertifikasi Auditor Syariah, Penetapan Kehalalan Produk, dan Akreditasi Lembaga Pemeriksa Halal (LPH) (MUI, 2016).
Pertimbangan halal dalam memilih sesuatu oleh seorang muslim sebagai konsumen dalam industri halal setidaknya dengan adanya label halal yang dicantumkan dalam prodaknya sekitar 31,1\% (Rambe \& Afifudiin: 2012) khususnya dalam industri halal makanan.

Selain itu, di sisi lain Industri halal atau wisata agama dan motivasi rohani telah menyebar luas dan menjadi populer dalam beberapa dekade terakhir, menempati segmen penting dari pariwisata internasional dan telah tumbuh secara substansial dalam beberapa tahun terakhir. Wisata religi menjadi salah satu bentuk pariwisata yang kurang dipelajari dalam penelitian pariwisata (Timothy\& Olsen, 2006:1). Data Global Islamic Economy Indicator 2017 menyebut Indonesia masuk 10 besar negara konsumen industri halal terbesar di dunia. Untuk belanja makanan halal , negara kita menempati peringkat nomor satu di dunia. Begitu pula di sektor pariwisata halal, Indonesia berada di urutan nomor lima di dunia. Sementara untuk obat-obatan dan kosmetika halal serta keuangan syariah, Indonesia menempati peringkat keenam dan kesepuluh di dunia (Nasar : 2017).

Dengan potensi perkembangan industri halal di Indonesia perlunya kajian hukum Islam salah satunya terkait maqashid syari'ah nya, yang menjadi bagian kerangka yang melandasi pembentukan invovasi, pengembangan, pengelolaan dan pemasaran industri halal di Indonesia. Maqashid Syariah merupakan bagian dari pada kajian hukum Islam untuk mengetahui maksud dan hikmah dari adanya perintah dan larangan dalam hukum Islam. Sehingga akal manusia selain hanya meyakini akan kebenaran wahyu melalui Al-Quran dan Sunnah, tetapi juga dapat memahami nilai-nilai maslahat yang dimaksud dalam setiap kandungan perintah menggunakan dan mengkonsumsi hal-hal yang halal dan thoyib sebagaimana firman Allah SWT yang telah disebutkan sebelumnya, khususnya dalam pengembangan industri halal di Indonesia, mengingat Indonesia menjadi pasar terbesar pengguna industri halal dunia. Dalam kerangka maqashid syari'ah hikmah atas sebuah ketentuan dalam Islam menjadikan manusia terlindungi dari kemafsadatan baik yang akan merugikan diri, keluarga dan lingkungan sekitar dari keburukan di dunia dan akhirat. Karena itu, melalui tulisan ini akan dibahas terkait Analisis maqashid Syariah 
dalam Pengembangan hukum Industri Halal di Indonesia.

\section{Perumusan Masalah}

Berdasarkan permasalahan di atas, maka kajian ini merumuskan permasalahan mengenai kajian analisis maqashid syariah dalam pengembangan hukum industri halal di Indonesia?

\section{Pembahasan}

\section{Pengertian Maqashid Syariah dan Industri Halal}

Secara etimologi, Maqasid al-Syari'ah merupakan kata majemuk yang terdiri dari dua kata yaitu: Maqasid dan al-Syari'ah. maqashid adalah bentuk jamak (plural) dari kata maqsad, qasd, maqsid, atau qusud yang merupakan derivasi dari kata kerja qasada-yaqsudu, dengan beragam makna dan arti antaranya menuju suatu arah, tujuan, tengah-tengah, adil, dan tidak melampui batas, jalan lurus, berada pada poros tengah antara berlebihan dan kekurangan. Sedangkan Syari'ah المواضع تحدر الي secara etimologi berarti artinya الماءJalan menuju sumber air, jalan menuju sumber air dapat juga diartikan berjalan menuju sumber kehidupan (Al-Qardhawi: $Y \cdots \vee, ~ I r)$. Orang arab dahulu menggunakan kata ini untuk menunjukkan suatu jalan ke tempat memperoleh air minum yang secara permanen dan mencolok dapat dipandang jelas oleh mata kepala. Dengan demikian, syariat berarti suatu jalan yang jelas untuk diikuti (the clear path or the highway to be followed) (Hasan: 1970, 17).

Secara ontologi maqūsid al-syarī, ah dilihat sebagai motivasi al-Syāri' (al-gharad/al-bāith/almuharrik), namun dibatasi dalam hal pensyariatan. Secara epistemologis, 2 maqāsid dalam wilayah pensyariatan masih dalam jangkauan pengetahuan manusia. Secara epistemologis manusia bisa membuktikan kebenaran maqāsid alSyāri berdasar maslahat yang terwujud dari hukum (Nurnazli : 2014, 45).

Berbagai kajian dalam literatur Islam khususnya kajian fikih dan Ushul Fiqh ditemukan bahwa term Maqasid al-Syari' ah sering digunakan dalam tiga bentuk redaksi yaitu maqsad al-syar' $i$, Maqasid al Syari'ah, dan al-syari'ah. Ketiga bentuk redaksi itu memiliki makna yang sama yaitu tujuan dan maksud syariat (Haddade: 2014, 42).
Adapun pengertian Industri berasal dari bahasa latin, yaitu industria yang artinya buruh atau tenaga kerja. Istilah industri sering digunakan secara umum dan luas, yaitu semua kegiatan manusia untuk memenuhi kebutuhan hidupnya dalam rangka mencapai kesejahteraan. Definisi Industri menurut Sukirno adalah perusahaan yang menjalankan kegiatan ekonomi yang tergolong dalam sektor sekunder. Kegiatan itu antara lain adalah pabrik tekstil, pabrik perakitan dan pabrik pembuatan rokok. Industri merupakan suatu kegiatan ekonomi yang mengolah barang mentah, bahan baku, barang setengah jadi atau barang jadi untuk dijadikan barang yang lebih tinggi kegunaannya (Sadono: 1995, 54).

Industri merupakan salah satu upaya untuk meningkatkan kesejateraan penduduk. Selain itu industrialisasi juga tidak terlepas dari usaha untuk meningkatkan mutu sumberdaya manusia dan kemampuan untuk memanfaatkan sumber daya alam secara optimal. Undang-Undang Nomor 5 Tahun 1984 tentang Perindustrian, industri adalah kegiatan ekonomi yang mengelola bahan mentah, bahan baku, barang setengah jadi, dan atau barang jadi menjadi barang dengan nilai yang lebih tinggi untuk penggunaanya termasuk kegiatan rancangan bangun dan perekayasaan industri. Dari sudut pandang geografi, Industri sebagai suatu sistem, merupakan perpaduan sub sistem fisis dan sub sistem manusia (Wignjosoebroto : 2003, 19).

Halal secara bahasa, menurut sebagian pendapat, berasal dari akar kata الحل yang artinya ( الإباحة) artinya sesuatu yang diboleh. menurut syariat (Qanaybî: 1985, 185). Al-Jurjani menulis, kata "halal " berasal dari kata الحل yang berarti " terbuka" (القتح). Secara istilah, berarti setiap sesuatu yang tidak dikenakan sanki penggunaannya atau sesuatu perbuatan yang dibebaskan syariat untuk dilakukan (AL-Jurnaji: 1405, 124).” Menurut Abû Ja'far al-Thabârî (224-310 H), lafaz halâl (حلال)berarti terlepas atau terbebas (طلقا). Dari beberapa penjelasan tersebut di atas, dapat ditarik kesimpulan halal adalah sesuatu yang di perbolehkan oleh syariat untuk dilakukan, digunakan, atau diusahakan, karena telah terurai tali atau ikatan yang mencegahnya atau unsur yang membahayakannya dengan disertai perhatian cara memperolehnya, bukan dengan hasil muamalah yang dilarang (Ali: 2016, 292).

Maka dari pengertian di atas dapat difahami bahwa industri halal adalah segala bentuk upaya 
dalam meningkatkan kesejahteraan penduduk baik berupa pengolahan bahan baku, dan pengembangan aspek lain yang dapat menjadi produk ekonomi yang diperbolehkan oleh syariat baik dalam proses pembuatan, usaha, penggunaannya, pemasarannya maupun pengembangannya bukan hasil dari kegiatan muamalah yang dilarang.

\section{Perkembangan dan Ruang Lingkup Industri Halal di Indonesia}

Potensi bisnis industri halal di dunia sangat besar. Saat ini berbagai negara, baik negara muslim maupun non-muslim berlomba-lomba menggarap potensi bisnis syariah. Berdasarkan laporan Global Islamic Economy Report 2016/2017 nilai belanja makanan dan gaya hidup (food and lifestyle sector expenditure) Muslim di sektor halal dunia mencapai US\$1,9 triliun pada tahun 2015 dan diperkirakan akan naik menjadi US\$ 3 pada tahun 2021. Global Islamic Economy Report 2016/2017 menempatkan Malaysia, United Arab Emirates dan Bahrain secara berurutan di peringkat teratas sebagai negara yang paling berkembang dalam industri halal di dunia. Malaysia menempati peringkat pertama karena kinerjanya yang kuat di sektor keuangan Islam dengan jumlah aset yang besar, pemerintahan yang maju dan memberikan dukungan penuh, dan memiliki nilai kesadaran tertinggi. Meskipun peringkat Malaysia di tahun 2016 sedikit menurun dalam indikator Halal Food yaitu diposisi kelima, namun ia berada diperingkat kedua dalam indikator Halal Travel and Halal Pharmaceuticals dan Cosmetics. Hal ini mencerminkan sektor pariwisata yang kuat dan sertifikasi produk halal yang canggih. Berdasarkan kriteria di atas, Malaysia dianggap layak menempati urutan pertama dalam industri halal dunia (Rasyid: 2017).

Dalam Global Islamic Economy Report 2016/2017 Indonesia menempati posisi 10, jauh tertinggal dari Malaysia yang berada di posisi pertama. Dari berbagai indikator yang ada, Indonesia dinilai kuat di bidang travel halal di mana pemerintah berperan aktif dalam mempromosikan hal tersebut. Namun di bidang lainnya dinilai relatif kuat. Tentu hal ini perlu menjadi perhatian kita bersama. Indonesia sebagai negara penduduk Muslim terbesar di dunia yang dikaruniai dengan berbagai sumber daya alam seharusnya bisa menjadi pemain utama di kancah nasional dan internasional khususnya di bidang industri halal . Namun peluang tersebut tidak dimanfaatkan dengan maksimal. Kebijakankebijakan pemerintah untuk mengembangkan industri halal belum terukur dan terencana dengan baik, sehingga terkesan kebijakan yang dikeluarkan untuk kepentingan sesaat lalu hilang tanpa kejelasan. Oleh sebab itu, perlu dukungan penuh pemerintah dalam hal mengembangkan industri halal di Indonesia (Rasyid: 2017).

Adapun ruang lingkup dalam industri halal di Indonesia berdasarkan UU No 33 tahun 2014 tentang Jaminan Produk Halal, adalah:
a. Makanan dan Minuman
b. Obat-obatan
c. Kosmetik,
d. Produk kimiawi
e. Produk biologi
f. Produk rekayasan genetic,
g. Barang gunaan yang dipakai, digunakan atau dimanfaatkan oleh masyarakat.

Selain itu, aspek lain dari industri halal yang lebih luas pun mencangkup pariwisata halal atau dikenal juga dengan pariwisata syari'ah yang meliputi objek wisata atau pun perhotelan. Dasar hukum aktivitas wisata halal berdasarkan pada Undang-Undang (UU) 10 Tahun 2009 tentang Kepariwisataan. Sebelumnya pemerintah sempat menerbitkan aturan teknis soal fasilitas penunjang wisata halal dalam bentuk Peraturan Menteri Pariwisata dan Ekonomi Kreatif Nomor 2 Tahun 2014 tentang Pedoman Penyelenggaraan Usaha Hotel Syariah. Aturan itu menetapkan dua kategori, yaitu hotel syariah hilal I dan hotel syariah hilal II.

Dalam perumusannya, pemerintah dibantu Dewan Syariah Nasional (DSN). Namun, akhirnya aturan itu dicabut dengan Peraturan Menteri Pariwisata Nomor 11 Tahun 2016 karena mendapatkan reaksi beragam dari kalangan industri. Lalu, pada 2016, Dewan Syariah Indonesia Majelis Ulama Indonesia (DSNMUI) mengeluarkan Fatwa Nomor 108/DSNMUI/X/2016 tentang Pedoman Penyelenggaraan Pariwisata Berdasarkan Syariah. Aspek pariwisata yang diatur di dalamnya antara lain, hotel, spa, sauna, dan massage, objek wisata, serta biro perjalanan. Namun, fatwa tersebut tidak akan berlaku efektif apabila tidak dipositifkan ke dalam bentuk peraturan menteri pariwisata. 


\section{Analisis Maqashid Syariah dalam Pengembangan Hukum Industri Halal di Indonesia}

Ulama menegaskan bahwa hukum Islam diciptakan untuk mewujudkan kemaslahatan manusia di dunia dan akirat. Kemaslahatan ada yang besifat primer (dharûriyyah), sekunder (hajiyyah), dan ada yang bersifat tersier (tahsiniyyah), sebagaimana dinyatakan Imam alGhazalî dan al-Syâthibî. Menurut Imam alSyâthibî, tugas syariah berorientasi pada terwjudnya tujuantujuan kemanusiaan yang terdiri atas bagian primer (dharûriyyah), sekunder (hajiyyah), dan tersier (tahsiniyyah). Primer, artinya sesuatu yang harus ada guna terwujudnya kemaslahatan agama dan dunia. Apabila sesuatu itu hilang, kemaslahaan manusia akan sulit terwujud, bahkan akan menimbulkan kerusakan, kekacauan dan kehancuran (Ali: 2016).

Di sisi lain, kebahagiaan dan kenikmatan akan lenyap dan kerugian yang nyata akan muncul. Untuk menjaga hal tersebut diperlukan dua hal. Pertama, sesuatu yang dapat menjaga dan mengukuhkan pondasi dan kaidah syariat dan merupakan aspek utama untuk menjaga keberadaan syariat. Kedua, sesuatu yang dapat mencegah pelanggaran langsung atau tidak langsung terhadap syariat dan merupakan aspek untuk menghindari kepunahan syariat. Imam al-Qarâfî menambahkan komponen ke enam, yaitu kehormatan yang sering disebut sebagai harga diri. Oleh karena itu syariat mengharamkan fitnah atau menuduh berzina (qadzaf), membicarakan aib orang lain (ghibah). Menurut Imam al-Syâthibî, kemaslahatan yang bersifat sekunder adalah segala hal yang dibutukan untuk memberikan kelonggaran dan mengurangi kesulitan yang biasanya menjadi kendala dalam mencapai tujuan. Adapun kemaslahatan yang bersifat keutamaan (tahsiniyyah) adalah melakukan tindakan yang lain menurut adat dan menjauhi perbuatan-perbuatan aib yang ditentang oleh akal sehat. Kemaslahatan ini merupakan keutamaan akhlak (Ali: 2016).

Apabila syariat bertujuan untuk menjaga kemaslahatan, ini dapat dipahami bahwa syariat bertujuan mencegah dan menghilangkan kerusakan-kerusakan. Prinsip ini ditegaskan dalam Hadis "Tidak ada kemudaratan dan tidak boleh memudaratkan " لاضرر و لاضرار". Hadis tersebut adalah Hadis Âhâd. Maksud Hadis ini "tidak ada kemudaratan dan tidak boleh memudaratkan", yaitu seseorang tidak boleh merusak dirinya dan orang lain. Tidak boleh memulai berbuat kerusakan atau membalas dengan kerusakan. Apabila kerusakan dan perbuatan merusak dilarang, kemaslahatan dan kesejahteraan akan terjaga dan ter pelihara. Dari hadis ini, ada ulama berkesimpulan bahwa pada prinsipnya kemudaratan itu haram. Kata mudarat yang dimuat dalam Hadis tersebut berbentuk umum (nakirah) dalam ungkapan peniadaan (nafiy). Dengan demikian yang dimaksud mudarat yaitu pelbagai jenis kerusakan. Sedangkan kemaslahatan (manâfi) pada prinsipnya adalah mubah. Imam Syâthibî mengisyaratkan bahwa pemeliharaan kemaslahatan atau tujuan- tujuan syariat dapat diwujudkan dalam dua bentuk, yaitu positif (ijâbiyyah) dan negatif (salabiyah). Positif dalam arti, syariat harus memelihara halhal yang dapat menegakkan dan mengukuhkan pilar-pilarnya dan dan negatif dalam arti, syariat mencegah pelanggaran langsung atau tidak langsung yang dapat merusaknya. Oleh karena itu mencegah kerusakan sangat diperlukan untuk menegakkan kemaslahatan (Ali: 2016).

Maqashid syariah merupakan bagian dari tasawur Islam (Islamic Worldview), yang dimaksudkan tasawur ini adalah cara pandang, gambaran atau sikap mental terhadap segala sesuatu berdasarkan nilai Islam. Pemahaman tentang suatu perkara yang meliputi aspek tauhid terhadap Allah sebagai Pencipta dan manusia sebagai hamba dan Khalifah Allah, yang terbangun dari bukti-bukti akal (aqli) dan bukti-bukti naqli (Al-Qur'an dan Hadis) (Mohd. Shukri, 2010). maqashid syariah meliputi berbagai macam Aspek seperti yang dikenalkan oleh Asy-Syatibi melalui ad-dharuriyah al-khamsa yang meliputi menjaga agama ( hifdzu ad-din), nyawa ( hifdz an-nafs), akal (hifdz al-'aql), keturunan (hifdz an-nasl) dan harta (hifdz al-maal). Akan tetapi, seharusnya maqashid syari'ah akan terus berkembang sesuai dengan tantangan zamannya, untuk memenuhi kebutuhan manusia akan setiap perkembangan tekhnologi ataupun kebutuhan manusia yang bersifat inovatif dan dinamis.

Perkembangan industri halal di Indonesia tidak terlepaskan dari tiga aspek penting , yaitu aspek produksi, distribusi dan konsumsi. Selain itu, ketiga aspek tersebut disertai dengan penggunaan tekhnologi yang semakin canggih dan inovatif sehingga perlu dikawal oleh sebuah aturan yang dalam hal ini hukum islam dalam 
kerangka maqashid syariah sehingga berimplikasi besar terhadap proses produksi, alat produksi, produk, pendistribusian serta pemilihan dalam aspek konsumsi masyarakat.

Malahan, Kamali (2008) mengusulkan agar memasukan pembangunan ekonomi dan pengukuhan $\mathrm{R}$ \& $\mathrm{D}$ teknologi dan sains dalam kajian maqashid syariah karena hal tersebut dianggap sangat penting dalam menentukan kedudukan umat islam di mata masyarakat dunia, khususnya dalam pembuatan produk halal juga terkait tuntunan agar maslahat untuk semua pihak.

Dari aspek produksi yang diantaranya mencangkup konsep dan keselamatan kerja dalam industri halal dapat difahami sebagai berikut:

1. Dalam aspek landasan dalam industri halal yang diterapkan adalah landasan tauhid, sehingga bukan hanya mengetengahkan aspek keuntungan duniawi saja akan tetapi aspek akhirat menjadi bagian penyeimbangnya. Aspek keselamatan manusia, alam dalam aktivitas produksi dalam memproduksi produk halal -thayiban menjadi bagian konsentrasi industry halal dalam kerangka maqashid syariah.

2. Dalam aspek tujuan dalam industri halal bukan hanya memfokuskan pada keuntungan yang maximal saja, akan tetapi selain keuntungan ada juga tanggung jawab yang harus dipertimbangkan dalam proses ataupun hasilnya. Sehingga mencegah dan menolak segala kemadharatan dan kemafsadatan baik untuk manusia maupun alam sekitar, menjadi prioritasnya juga.

3. Dalam aspek pengupahan pekerja sesuai dengan usaha yang dilakukan dalam pekerjaannya, bahkan upah yang sesuai tersebut dalam kerangka maqashid syariah agar dapat diberikan sebelum keringat sang pekerja kering yang bertumpu pada kelaziman dalam mengupah. Selain itu, selain nilai materil juga dikembangkan konsep berkah dalam usaha industri halal .

Maka ketika aspek maqashid syariah menjadi kerangka dalam perjalanan perkembangan industri halal di Indonesia, sehingga menjadikan resiko kemadharatan dan kemafsadatan dapat dihindari atau ditekan seminimal mungkin. Karena kemadharatan atau bahaya yang ditimbulkan dari sebuah industri tersebut menjadi bagian dari manajemen resiko yang harus diperhatikan. Dalam maqashid syariat menjaga nyawa ( $h i f d z$ an$n a f s$ ) dalam proses produksi, distribusi maupun konsumsi dalam industri halal tersebut harus menjadi fokus utama, sehingga proses produksi dan hasil dari produksi yaitu produknya terjamin melalui adanya setifikasi halal yang dilakukan oleh lembaga-lembaga yang berwenang dalam mengeluarkan izin halal sebuah produk atau jasa. Dengan adanya keseimbangan antara hak dan kewajiban antara konsumen dan produsen dalam industri halal dapat berjalan semestinya serta hal tersebutlah yang menjadi bagian tujuan dari maqashid syariah.

\section{Simpulan}

Pemahaman dan semangat dalam mengaplikasikan konsep halal dan thoyib dalam ranah industri halal di Indonesia seharusnya memiliki semangat dan motivasi dalam kerangka maqashid syariah, sehingga perkembangan industri halal tersebut dapat sejalan dengan tujuan utamanya agar para konsumen di Indonesia khususnya bagi masyarakat muslim terjaga dalam segala segi pemenuhan kebutuhannya yang dipenuhi kebutuhan tersebut melalui industri halal yang bersifat dinamis dan inovatif, serta senantiasa dalam rangka menjaga kemaslahatan bagi semua pihak.

\section{Daftar Pustaka}

Al-Jurjanî, A. M.A. 1405. Tahqî̀ Ibrâhîm alAbyarî. Bayrût: Dâr al-Kitâb al- 'Arabî.

Ali, M. 2016. Konsep Makanan Halal dalam Tinjauan Syariah dan Tanggung Jawab Produk Atas Produsen Industri Halal . Jurnal Al-Ahkam. Vol.XVI, No. 2, Juli 2016.

Al- Syatibi. T.th. al-Muwafaqat fi Ushul alSyari'ah. Kairo: Mustafa Muhammad.

Al- Qaradhawi, Y. 2007. Fiqh maqashid Syariah:Moderasi Islam antara Aliran Tekstual dan Aliran Liberal. Jakarta: Pustaka Al-Kautsar. 
Hasan, A. 1970. The Early Development of Islamic Jurisprudence. Islamabad: Islamic Research Institute.

Haddade, A. W. 2014. Kontruksi Ijtihad Berbasis maqashid Al-Syari'ah: Membincang formulasi konsep Ibnu 'Asyur dan Relevansinya dengan Wacana Fikih Kontemporer . Makassar: Alauddin University Press .

Nasar, M. F. 2017. Negara dan Sertifikasi Halal di Indonesia. https://kemenag.go.id/berita/ read/505898/negara-dan-sertifikasi-halal -indonesia.

Nurnazli. 2014. Penerapan Kaidah maqashid Syriah dalam Produk Perbankan Syariah. Jurnal Ijtimaiyah, jurnal pengembangan masyarakat, Vol. 7 No.1 Februari 2014.

Qal'ajî, M. R. \& Qanaybî, M. S. 1985. Mu'jam Lughah al-Fuqahâ. Bayrût: Dâr al-Fikr.

Rambe, Y. M. \& Afifuddin, S. 2012. Pengaruh Pencantuman Label Halal Pada Kemasan Mie Instan Terhadap Minat Pembelian Masyarakat Muslim. Jurnal Ekonomi dan Keuangan, Vol. 1, No. 1.

Rasyid, A. 2017. Roadmap Industri Halal di Indonesia. $\quad \mathrm{http} / / /$ business-law.binus. ac.id/2017/05/31/roadmap-industri-halal -di-indonesia/

Ramli, A. et.al. 2016. Pembangunan Industri Halal : Konsep Halal an-Toyyiban dan Pengurusan Keselamatan Industri dalam Kerangka Maqasid asy-Syari'ah. Kuala Lumpur: Journal 'Ulum Islamiyyah Universiti Sains Islam Malaysia. Vol.18 Desember . pp.91-114.

Sadono, S. 1995. Pengantar Teori Ekonomi Mikro. Jakarta : PT. Karya Grafindo Persada.

Wignjosoebroto, S. 2003. Pengantar Teknik \&Manajemen Industri. Jakarta: Penerbit Guna Widya .

http://www.halal mui.org/ newMUI/30September2016.pkl.10.05 